Cybernetics: Journal Educational Research and Social Studies

Volume 2, Nomor 3, Juli 2021

Journal Homepage: http://pusdikra-publishing.com/index.php/jrss

\title{
Hukum Dalam Bentuk Kompensasi Bagi Korban Pelanggaran Ham Berat Dari Perspektif UU No 26 Tahun 2000
}

\section{Teti Winarti}

\section{Kementerian Hukum dan HAM}

\begin{tabular}{|c|c|}
\hline & ABSTRACT \\
\hline & $\begin{array}{l}\text { Indonesia sebagai bagian dari komunitas negara-negara di dunia, sekalipun telah } \\
\text { ikut menyetujui statuta ini, sampai sekarang belum melakukanratifikasi dalam } \\
\text { hukum nasionalnya, sekalipun sekarang ini telah memiliki Undang-Undang } \\
\text { nomor } 26 \text { tahun } 2000 \text { tentang Pengadilan Hak Asasi Manusia. Itu artinya, belum } \\
\text { ada harmonisasi instrument hukum internasional pada sistem hukum } \\
\text { nasionalnya terkait dengan ICC, walaupun diakui di dalam UU tersebut bahwa } \\
\text { muatan materinya sebagian berkiblat pada Statuta Roma. Dalam hal ini } \\
\text { pengadopsian dan lahirnya UU No } 26 \text { Tahun } 2000 \text { inididasari dan memiliki } \\
\text { landasan hukum dalam konstitusi negara, deklarasi universal tentang HAM, } \\
\text { Ketetapan MPR RI nomor: XVII/MPR/1998 tentang Hak Asasi Manusia dan } \\
\text { Undang- Undang nomor: } 39 \text { tahun } 1999 \text { tentang Hak Asasi Manusia, yang harus } \\
\text { dilaksanakan dengan penuh rasa tanggung jawab sesuai dengan falsafah negara } \\
\text { Pancasila UU nomor } 26 \text { tahun } 2000 \text { dapat di katakana sebagai suatu bentuk } \\
\text { penegasan terhadap perlindungan terhadap Hak Asasi Manusia yang telah di } \\
\text { atur di dalam Undang- Undang nomor: } 39 \text { tahun } 1999 \text { tentang Hak Asasi } \\
\text { Manusia, akan tetapi dalam hal ini lebih terkhususnya terhadap pelanggaran } \\
\text { HAM berat yang merupakan produk kebijakan criminal "model kompromi" } \\
\text { sebab tidak semua ketentuan dalam UU tersebut persis sama dengan ketentuan } \\
\text { yang diatur oleh Statuta Roma. }\end{array}$ \\
\hline Kata Kunci & Kompensasi, HAM, UU No.26 Tahun 2000 \\
\hline
\end{tabular}

\section{PENDAHULUAN}

Indonesia adalah Negara yang berdasarkan hukum, hal tersebut tertuang dalam Undang-Undang Dasar Pasal 1 ayat (3) UUD 1945 yang menyatakan negara Indonesia adalah negara hukum. ${ }^{1}$ Adapun tujuan pokok hukum adalah menciptakan tatanan masyarakat yang tertib, menciptakan ketertiban dan keseimbangan. Dengan tercapainya ketertiban di dalam masyarakat diharapkan kepetingan manusia akan terlindungi. ${ }^{2}$

Sehubungan dengan hal tersebut, Hak Asasi Manusia (HAM) perlu mendapat perhatian yang sungguh-sungguh, karena mempunyai dimensi pengaruh yang sangat besar yaitu meliputi kehidupan masyarakat nasional maupun internasional. Dalam ruang lingkup nasional, hukum positif Indonesia yang mengatur tentang HAM diatur dalam pasal 1 angka 1 Undang-Undang No 39 tahun 1999 tentang Hak Asasi Manusia

Indonesia sebagai bagian dari komunitas negara-negara di dunia, sekalipun telah ikut menyetujui statuta ini, sampai sekarang belum melakukan 
Cybernetics: Journal of Research and Educational Studies

Volume 2 Nomor 3, Juli 2021

Halaman 107-116

ratifikasi dalam hukum nasionalnya, sekalipun sekarang ini telah memiliki Undang-Undang nomor 26 tahun 2000 tentang Pengadilan Hak Asasi Manusia. Itu artinya, belum ada harmonisasi instrument hukum internasional pada sistem hukum nasionalnya terkait dengan ICC, walaupun diakui di dalam UU tersebut bahwa muatan materinya sebagian berkiblat pada Statuta Roma.

Dalam hal ini pengadopsian dan lahirnya UU No 26 Tahun 2000 inididasari dan memiliki landasan hukum dalam konstitusi negara, deklarasi universal tentang HAM, Ketetapan MPR RI nomor: XVII/MPR/1998 tentang Hak Asasi Manusia dan Undang- Undang nomor: 39 tahun 1999 tentang Hak Asasi Manusia, yang harus dilaksanakan dengan penuh rasa tanggung jawab sesuai dengan falsafah negara Pancasila UU nomor 26 tahun 2000 dapat di katakana sebagai suatu bentuk penegasan terhadap perlindungan terhadap Hak Asasi Manusia yang telah di atur di dalam Undang- Undang nomor: 39 tahun 1999 tentang Hak Asasi Manusia, akan tetapi dalam hal ini lebih terkhususnya terhadap pelanggaran HAM berat yang merupakan produk kebijakan criminal "model kompromi" sebab tidak semua ketentuan dalam UU tersebut persis sama dengan ketentuan yang diatur oleh Statuta Roma.

Persoalan ini yang kemudian memunculkan banyak kritik terutama dari para aktivis dan penggiat HAM seperti yang dilakukan oleh Amnesty Internasional dalam laporannya pada bulan Pebruari 2001, antara lain memunculkan kekhawatiran terdapatnya pasal-pasal dalam UU Pengadilan HAM yang tidak cocok atau tidak sesuai dengan definisi menurut hukum internasional. Menurut UU No 26 Tahun 2000 ini, pelanggaran Hak Asasi Manusia yang berat meliputi kejahatan genosida dan kejahatan terhadap kemanusiaan (pasal 7).

Keberpihakan hukum terhadap pelaku, tidak seimbang dengan keberpihakan hukum terhadap Korban. Hal ini terlihat dalam beberapa peraturan yang lebih banyak memberikan hak-hak istimewa kepada tersangka maupun terdakwa. KUHAP sebagai landasan untuk beracara dalan perkara pidana cenderung lebih banyak memberikan porsi perlindungan kepada terdakwa dan tersangka dari pada kepada korban. Mereka tidak mendapatkan hak-hak yang seharusnya mereka terima sebagai korban, misalnya tidak mendapatkan hak-hak pemulihan bagi dirinya maupun keluarganya. ${ }^{15}$ tetapi obyek perhatian ternyata masih lebih terfokus kepada bagaimana memberikan hukuman kepada sipelaku tindak pidana, dan hal itu masih melekat pada fenomena pembalasan belaka. di Indonesia dan praktik-praktik pemenuhan hak atas kompensasi dan restitusiselama ini.Utamanya terhadap Pelanggaran HAM berat. 
Cybernetics: Journal of Research and Educational Studies

Volume 2 Nomor 3, Juli 2021

Halaman 107-116

Berdasarkan uraian di atas maka penelitian ini mengangkat judul karena alasan-alasan sebagai berikut:

1) Bahwa HAM merupakan hak dasar yang secara kodrati melekat pada diri manusia yang harus dilindungi, dihormati, dipertahankan, dantidak boleh diabaikan, dikurangi, atau dirampas oleh siapapun, dan juga merupakan salah satu yang menjadi yang mendapat pengakuan dalam ruang lingkup masyarakat Nasional maupun Internasional yang harus di junjung tinggi dan di tegakkan.

2) Bahwa keberpihakan hukum terhadap pelaku tindak pidana tidak seimbang dengan keberpihakan hukum terhadap korban karena perkembangan hukum pidana saat ini lebih ke arah pembinaan terhadap pelaku tindak pidana termasuk sistem pemidanannya yang lebih berfokus kepada bagaimana pemberian hukuman kepada sipelaku tindak pidana, seingga korban tindak pidana luput dari perhatian dan tidak mendapat hak-hak yang seharusnya mereka terimasebagai korban tindak pidana.

\section{Pengertian Korban}

Korban adalah seseorang yang mengalami penderitaan fisik, mental, dan/atau kerugian ekonomi yang diakibatkan oleh suatu tindak pidana. Korban suatu kejahatan tidak selalu harus berupa individu, atau orang perorangan, tetapi bisa juga badan hukum.Bahkan pada kejahatan tertentu, korban bisa juga berasal dari bentuk kehidupan lainnya seperti tumbuhtumbuhan, hewan atau ekosistem.Korban semacam ini lazim kitatemui dalam kejahatan terhadap lingkungan.Namun dalam pembahasan ini korban sebagaimana dimaksud terakhir tidak termasuk di dalamnya.

Dalam perspektif ilmu pengetahuan hukum pidana lazimnya pengertian "korban kejahatan" merupakan terminologi disiplin ilmu kriminologi dan victimologi yang kemudian dikembangkan dalam sistem peradilan pidana. Berdasarkan perspektif ilmu victimologi, pengertian korban dapat diklasifikasikan secara luas dan sempit.Dalam pengertian luas korban diartikan sebagai orang yang menderita atau dirugikan akibat pelanggaran baik bersifat pelanggaran hukum pidana (penal) mupun diluar hukum pidana (non penal) atau dapat juga termasuk korban penyalahgunaan kekuasaan (victim abuse of power).Sedangkan pengertian korban dalam artian sempit dapat diartikan sebagai victim of crime yaitu korban kejahatan yang diatur dalam ketentuan hukum pidana. ${ }^{18}$ Diklasifikasi secara global menjadi:

1. Korban kejahatan (victims of crime) sebagaimana termasuk dalam ketentuan hukum pidana sehingga pelaku (offender) diancam dengan penerapan sanksi pidana. Pada konteks ini maka korban diartikan sebagai penal victimology dimana ruang lingkup kejahatan meliputi kejahatan tradisional, 
Cybernetics: Journal of Research and Educational Studies

Volume 2 Nomor 3, Juli 2021

Halaman 107-116

kejahatan kerah putih (white collar crime), serta victimless crimes yaitu viktimasasi dalam korelasinya dengan penegak hukum, pengadilan dan lembaga pemasyarakatan,

2 Korban akibat penyalagunaan kekuasaan (victims abuse of power). Pada konteks ini maka lazim disebutkan dengan terminologi political victimology dengan ruang lingkup abuse of power, Hak Asasi Manusia (HAM) danterorisme,

3. Korban akibat pelanggaran hukum yang bersifat administratif atau yang bersifat non penal sehingga ancaman sanksinya adalah sanksi yang bersifat administratif bagi pelakunya. Pada konteks ini lazimnya ruang lingkupnya bersifat economic victimology, dan

4. Korban akibat pelanggaran kaedah sosial dalam tata pergaulan bermasyarakat yang tidak diatur dalam ketentuan hukum sehingga sanksinya bersifat sanksi sosial atau sanksimoral. ${ }^{19}$

Berbagai pengertian korban banyak dikemukakan baik oleh paraahli maupun bersumber dari konvensi-konvensi internasional yang membahas mengenai korban kejahatan, sebagian diantaranya adalah sebagai berikut:Arif Gosita, menurutnya korban diartikan sebagai, "mereka yang menderita jasmaniah dan rohaniah sebagai akibat tindakan orang lain yang mencari pemenuhan kepentingan diri sendiri atau orang lain yang bertentangan dengan kepentingan dan hak asasi yang menderita".20

Berikut yang dimaksud "mereka" oleh Arif Gosita disini adalah:

1. Korban orang perorangan atau korban invidual (viktimasasiprimair),

2. Korban yang bukan perorangan, misalnya, suatu badan, organisasi, lembaga. Pihak korban adalah impersonal, komersial, kolektif (viktimisasi sekunder) adalah keterlibatan umum, keserasian sosial dan pelaksanaan perintah, misalnya pada pelanggaran peraturan dan ketentuan-ketentuan negara (viktimisasitersier).

\section{Pengertian Kompensasi}

Kompensasi adalah ganti kerugian yang diberikan oleh Negara karena pelaku tidak mampu memberikan ganti kerugian sepenuhnya yang menjadi tanggung jawabnya. ${ }^{22}$ Dalam hal kompensasi dan atau rehabilitasi menyangkut pembiayaan dan perhitungan keuangan negara, pelaksanaannya dilakukan oleh Departemen Keuangan. ${ }^{23}$ Selain itu Pemberian kompensasi dan restitusi juga dapat kita lihat dalam Peraturan Pemerintah Nomor 2 tahun 2002 tentang kompensasi, restitusi dan rehabilitasi terhadap korban pelanggaran HAM berat; dan Peraturan Pemerintah Nomor 44 Tahun 2008 tentang pemberian kompensasi, restitusi, bantuan. Menurut ketentuan Pasal 8 Undang-Undang Perlindungan Saksi dan Korban menentukan bahwa perlindungan dan hak 
Cybernetics: Journal of Research and Educational Studies

Volume 2 Nomor 3, Juli 2021

Halaman 107-116

korban diberikan sejak tahap penyelidikan dimulai dan berakhir sesuai dengan ketentuan sebagaimana diatur dalam Undang - Undang. ${ }^{24}$

Kompensasi, diberikan untuk setiap kerusakan yang secara ekonomis dapat diperkirakan nilaianya, yang timbul dari pelanggaran hak asasi manusia, seperti:

1) kerusakan fisik dan mental;

2) kesakitan, penderitaan dan tekanan batin;

3) kesempatan yang hilang, termasuk pendidikan;

4) hilangnya mata pencaharian dan kemampuan mencari nafkah;

5) biaya medis dan biaya rehabilitasi lain yang masuk akal, termasuk keuntungan yang hilang;

6) kerugian terhadap reputasi dan martabat;

7) biaya dan bayaran yang masuk akal untuk bantuan hukum atau keahlianuntuk memperoleh suatu pemulihan;

8) kerugian terhadap hak milik usaha, termasuk keuntungan yang hilang.

\section{METODE PENELITIAN}

Jenis penulisan hukum yang di gunakan dalam penulisan ini ialah penelitian hukum normatif atau penelitian hukum kepustakaan, yaitu penelitian yan di lakukan dengam cara meneliti bahan pustaka atau data skunder belaka. Penelitian hukum normatif atau kepustaan tersebut mencakup.

a. Penelitian terhadap asas-asas hukum;

b. Penelitian terhadap sistematika hukum;

c. Penelitian terhadap sinkronoisasi vertical dan horizontal.

d. Perbandingan hukum;

e. Sejarah hukum.

Penelitian hukum normatif memerlukan bahan hukum yang berupa bahan hukum primer, bahan hukum skunder dan bahan hukum tersier dan bahan hukum nonhukum.

a. Bahan hukum primer yaitu bahan hukum yang terdiri dari peraturan perundang-undangan yang mendasari dan berkaitan dengan penulisan ini, atara lain;

1) Undang-undang dasar Negara Republik Indonesia,

2) Undang-undang No 26 Tahun 2000 tentang Pengadian HAM

3) Peraturan Pemerintah No 3 tahun 2002 tentang Kompensasi, Restitusi, danRehabilitasi Terhadap Korban Pelanggaran HAM Berat.

4) Undang-Undang Nomor 39 Tahun 1999 tentang Hak Asasi Manusia,

5) Undang-undang No. 27 tahun 2004 tentang Komisi Kebenaran dan Rekonsiliasi 
Cybernetics: Journal of Research and Educational Studies

Volume 2 Nomor 3, Juli 2021

Halaman 107-116

6) Peraturan Pemerintah Nomor 44 Tahun2008

tentang PemberianKompensasi, Restitusi, Bantuan, Kepada Saksi dan Korban,

7) Undang-Undang No 31 Tahun 2014 tentang Perlindungan Saksi dan Korban,

b. Bahan hukum sekunder yaitu kajian teoritis yang berupa pendapat hukum, ajaran atau doktrin dan teori hukum sebagai penunjang bahan hukum primer yang diproleh dari hasil, buku teks, jurnal ilmiah serta penelusuran penulis mengenai hal- hal yang berjaitan dengan penulisan karya ini diinternet.

c. Bahan hukum tersier dan atau bahan non hukum yaitu bahan penulisan yang dapat menjelaskan bahan hukum primer maupun bahan hukum sekunder,yaitu berupa kamus dan bahan nonhukum lainnya.

Tehnik pengambilan data yang di lakukan dalam penulisan ini di peroleh dengan cara penelitian kepustakaan terhadap bahan penelitian. metode yang digunakan dalam penulisan skripsi ini ialah pendekatan kualitatif berupa analisis data yang tidak menggunakan angka tetapi berdasarkan aturan PerundangUndangan, literatur-literatur sehingga dapat menjawabpermasalahan yang di tulis, yaitu metode analisis yang memberikan penilaian terhadap obyek di tulis oleh penulis. Dengan menggunakan metode ini di harapkan nantinya dapat memberikan gambaran mengenai teori berdasarkan peratuan perundangundangan yang berlaku serta penerapannya dalam prakek persidanagan sehingga disparitas dalam pertimbangan hakim itu dapat di terima masyarakat.

\section{HASIL DAN PEMBAHASAN}

Pelanggaran HAM berat berupa Kejahatan genosida, kejahatan terhadap kemanusiaan, kejahatan perang dan agresi adalah kejahatan- kejahatan yang di definiskan dalam Statuta Roma sebagai kejahatan paling serius yang menyangkut masyarakat internasional secara keseluruhan (the most serious crimes of concern to the international community as a whole). ${ }^{29}$

Kejahatan-kejahatan tersebut dikategorikan paling serius atau merupakan kejahatan yang paling buruk (worst crime) karena dalam sejarahnya kejahatan ini telah menggoncangkan nurani umat manusia (shocking consciousness of humanity) dan para pelakunya adalah state officials. Kekejaman tentara Jepang pada perang dunia II, dan dalam abad modern ini adalah pembantaian di bekas Yugoslavia dan Rwanda menunjukkan potret kelam dalam peradaban manusia. bukan saja jumlah korban yang mencapai ribuan, tetapi dilakukan secara sistematis dengan kebijakan politik tertentu. 
Sejumlah pengadilan digelar untuk mengadili kejahatan-kejahatan serius tersebut. Penghukuman atas kejahatan-kejahatan tersebut telah dilakukan sejak adanya Pengadilan Nurenberg dan Pengadilan Tokyo pada tahun 1948. Selanjutnya, pada tahun 1993 digelar Pengadilan Pidana International ad hoc untuk mengadili pelaku berbagai pelanggaran serius terhadap hukum humaniter internasional di negara bekas Yugoslavia. Pada tahun 1994 juga dibentuk Pengadilan Pidana Internasional ad hoc untuk mengadili kejahatan genosida, dan kejahatan terhadap kemanusiaan yang terjadi di Rwanda. Sejumlah regulasi juga disiapkan untuk menuntut para pelakunya. ${ }^{30}$

Berawal dari Piagam Nurenberg, istilah kejahatan terhadap kemanusiaan dan kejahatan perang muncul dan untuk pertama kalinya dan juga mengakui dan menetapkan bahwa kejahatan tersebut harus diadili. Sementara, genosida pun merupakan kejahatan serius yang pada saat itu dimasukkan kedalam kejahatan terhadap kemanusiaan. Berdasarkan piagam ini, Pengadilan Militer Nurenberg diadakan, dan selanjutnya diikuti dengan penyelenggaraan Mahkamah Pidanauntuk Timur Jauh (International Military Tribunal for Far East) di Tokyo. Kemudian Konvensi Genosida tahun 1948 tentang Pencegahan dan Penghukuman bagi Kejahatan Genosida. Konvensi ini tidak hanya melarang kejahatan genosida, namun juga melarang segala bentuk tindakan yang "mengarahkan dan menghasut publik untuk melakukan genosida". Dapat dicegah dan tidak akan terulang di kemudian hari. Karena pada hakikatnya, keadilan yang tertunda akan meniadakan keadilan itu sendiri (justice delayed can be justice denied) .Sejarah Penegakan HAM Berat Dalam Ruang Lingkup Nasional berdasarkan Statuta Roma menjadi tonggak sejarah dalam penegakan pelanggaran HAM di berbagai negara akan tetapi Indonesia sebagai negara yang telah berkomitmen dalam penegakan pelanggaran HAM belum melakukan adopsi secara maksimal Statuta Roma padahal hal ini telah tercantum dalam Rencana Aksi Nasional Hak Asasi Manusia

Disamping itu, peristiwa penting lainnya yang mempercepat lahirnya mekanisme perlindungan Hak Asasi Manusia di Indonesia adalah adanya tuntutan dari masyarakat internasional melalui Komisi HAM PBB, agar pemerintah Indonesia segera membentuk suatu mekanisme pertanggungjawaban atas kemungkinan adanya pelanggaran hak asasi manusia dan pelanggaran hukumhumaniter internasional di Timor-Timur sejak Januari 1999.

Berdasarkan ketentuan Undang-Undang Nomor 26 Tahun 2000 tentang Pengadilan HAM, maka ada 2 (dua) bentuk pengadilan yang dikenal dalam undang-undang ini. Pertama, untuk peristiwa pelanggaran HAM yang terjadi sebelum disahkannya Undang-Undang tersebut, diperiksa dan diputus oleh 
Cybernetics: Journal of Research and Educational Studies

Volume 2 Nomor 3, Juli 2021

Halaman 107-116

Pengadilan HAM ad hoc (Pasal 43 ayat (1)) yang pembentukan pengadilannya memerlukan usulan dari parlemen (DPR RI) untuk kemudian diputuskan lewat Keputusan Presiden (Keppres). Kedua, untuk peristiwa pelanggaran HAM yang terjadi setelahnya diperiksa dan diputus oleh Pengadilan HAM permanen.

Pengadilan HAM berwenang memeriksa dan mengadili perkara pelanggaran HAM yang berat. Kewenangan untuk memutus dan memeriksa juga termasuk menyelesaikan perkara yang menyangkut permohonan kompensasi, restitusi (dan rehabilitasi) bagi korban pelanggaran HAM berat. ${ }^{40}$ Kewenangan untuk memutus tentang kompensasi, restitusi dan rehabilitasi ini sesuai dengan Pasal 35 UU No. 26 Tahun 2000 yang menyatakan bahwa kompensasi, restitusi dan rehabilitasi dicantumkan dalam dalam amar putusan Pengadilan HAM.

\section{Korban Pelanggaran HAM Berat.}

Pelanggaran Hak Asasi Manusia dikatagorikan atas dua macam yaitu pelanggaran biasa (isolated crime), dan pelanggaran Hak Asasi Manusia berat (gross violation of human rights) atau sering disebut extra ordinary crimes. ${ }^{41}$ Pelaku pelanggaran Hak Asasi Manusia dapat dikatagorikan dalam tiga katagori yakni pemerintah, kelompok dan individu. ${ }^{42}$ Berdasarkan dari segi hubungan hukum dan Hak Asasi Manusia, maka pada prinsipnya pelanggaranHak Asasi Manusia adalah pelanggaran hukum, akan tetapi dalam pembasan ini akan lebih terfokus terhadap korban pelanggaran HAM berat. Mental maupun emosional, kerugian ekonomi, atau mengalami pengabaian, pengurangan atau perampasan hak-hak dasarnya, sebagai akibat pelanggaran Hak Asasi Manusia yang berat, termasuk korban adalah ahli warisnya."

Selain itu pengertian mengenai korban dapat ditemukan dalam Deklarasi Prinsip-prinsip Dasar Keadilan bagi Korban Kejahatan danPenyalahgunaan Kekuasaan (Declaration of BasicPrinciples of Justice for Victims of Crimes and Abuse of Power) yang diadopsi berdasarkan Resolusi Majelis Umum PBB No.40/34 tertanggal 29 November 1985, yaitu berbunyi sebagai berikut.

"Victim means persons who, individually or collectively, have suffered harm, including physical or mental injury, emotional suffering, economic loss or substantial impairment of their fundamental rights, through acts or omissions that are in violation of criminal laws operative with Member States, including those laws proscribing criminal abuse of power. (Korban adalah orang yang secara individu atau kolektif, telah menderita kerugian, termasuk luka fisik atau mental, penderitaan emosional, kerugian ekonomi atau perusakan yang substansial atas hak dasarnya, lewat tindakan atau pembiaran yang bertentangan dengan hukum pidana yang berlaku di negara-negara anggota, termasuk hukum yang melarang penyalahgunaan kekuasaan yang bisa dikenai pidana.)" 
Cybernetics: Journal of Research and Educational Studies

Volume 2 Nomor 3, Juli 2021

Halaman 107-116

Apabila dicermati lebih terperinci ternyata perlindungan korban kejahatan bersifat perlindungan abstrak atau perlindungan tidak langsung yang dirumuskan dalam kebijakan formulatif yaitu perlindungan abstrak dimana cenderung mengarah pada perlindungan masyarakat dan individu.

\section{KESIMPULAN}

Berdasarkan hasil penelitian dan pembahasan bab-bab sebelumnya, maka dapat ditarik kesimpulan sebagai berikut:

1. Pengaturan tentang kompensasi terhadap korban pelanggaran HAM berat menurut peraturan Perundang-Undangan di Indonesia, secara tegas diakui dan diatur dalam Peraturan Perundang-Undangan di Indonesia di antaranya;

a. UU No 26 tahun 2000 tentang Pengadilan HAM.

Secara tegas dalam Pasal 35 ayat (1) UU No. 26 Tahun 2000 menyatakan bahwa: "Setiap korban pelanggaran hak asasi manusia yang berat dan atau ahli warisnya dapat memperoleh kompensasi, restitusi, dan rehabilitasi". Penjelasan Pasal 35 menyebutkan bahwa yang dimaksud dengan "kompensasi" adalah ganti kerugian yang diberikan oleh negara, karena pelaku tidak mampu memberikan ganti kerugian sepenuhnya yang menjadi tanggung jawabnya.

b. UU No.13 Tahun 2006 tentang Perlindungan Saksi danKorban.

Dalam Undang-Undang ini, sebagaimna yang tercantum dalamPasal 7 UU No. 13 Tahun 2006, menentukan:Korban melalui LPSK berhak mengajukan ke pengadilan berupa:

1. hak atas kompensasi dalam kasus pelanggaran HAM yang berat;

2. hak atas restitusi atau ganti kerugian yang menjadi tanggungjawab pelaku tindakpidana".

b. Kompensasi yang di berikan terhadap korban pelanggaran HAM berat di Indonesia belum sepenuhnya berjalan sebagaimaa yang seharusnya sesuaiyang di atur dalam berbagai peraturan Perundang-Undagan di Indonesia..

c. Perbandingan hukum nasional (UU No 26 tahun 2000) dengan hukum internasional (Statuta Roma 1998) mengenai Kompensasi terhadap pelanggaran HAM berat. Bahwa berdasarkan persamaan dan perbedaan yang telah di jelaskan dalam pembahasan bab IV dapat di tarik kesimpulan bahwa sistem hukum Indonesia perlu ratifikasi terhadap Statuta Roma mengingat terdapatnya beberapa kesalahan dalam perumusanyang mengakibatkan terjadinya implikasi yang berbeda dari yang seharusnnya berdasarkan Statuta Roma, serta Proses 
peratifikasian dan pengaturan lain yang belum memadai dari yang seharusnya dalam Statuta Roma sebagaimana yang sudah di jelaskan lebih rangkum dalam bab IV, sehingga dengan melakukan ratifikasi dapat menjadi upaya pencegahan kemungkinanterjadinya kejahatan dengan akibat yang lebih besar di kemudian hari, serta memudahkan praktisi hukum dalam menjalankan suatu proses hukum yang memadai. Sehingga dapat memberikan perlindungan dan reparasi bagi korban pelanggaran HAM berat.

\section{DAFTAR PUSTAKA}

\section{Buku}

Sudikno Mertokusumo, 2005, Mengenal Hukum Suatu Pengantar, Yogyakarta: Liberty, hal 77. Mardjono Reksodiputro Kriminologi dan Sistem Peradilan Pidana, (Jakarta: Pusat Pelayanan Keadilan dan Pengabdian Hukum (d/h Lembaga Kriminologi Universitas Indonesia, 2007a), hal. 76

Supriyadi Widodo Eddyono, et.al., ed., "Perlindungan Saksi dan Korban Pelanggaran HAM Berat", Seri Kampanye RUU Perlindungan Saksi \# 2, (Jakarta: Lembaga Studi dan Advokasi Masyarakat (ELSAM)), hal. 2.

Dikdik M. Arief Mansur \& Elisatris Gultom, Urgensi Perlindungan Korban Kejahatan, (Jakarta: PT RajaGrafindo, 2007), hal.45-46.

Lilik Mulyadi, Kompilasi Hukum Pidana dalam Perspektif Teoritis dan Praktik Peradilan Pidana (Perlindungan Korban Kejahatan, Sistem Peradilan dan Kebijakan Hukum Pidana, Filsafat Pemidanaan serta Upaya Hukum Peninjauan kembali oleh Korban Kejahatan), (Bandung: Penerbit CV. Mandar Maju, 2010), hal.1-2.

Arif Gosita, Masalah Perlindungan Anak (Kumpulan Karangan), (Jakarta: PT. Bhuana Ilmu Populer, 2004), hal. 96.

O-Anne Wemmer, Victims and Criminal Justice Sistem, (Amsterdam: Kugler Publication, 1996), hal.35.

Soerjono Soekanto dan Sri Mamudji, Penelitian Hukum Normatif: suatu tinjauan singkat, PT. Raja Grafindo Persada Jakarta, 1995. Hal 13-14

Sriwiyanti Eddyono \& Zainal Abidin, Tindak Pidana Hak Asasi Manusia dalam RKUHP, (Jakarta: ELSAM dan Aliansi Nasional Reformasi KUHP, Cetakan Pertama, 2007), hal. 7-8.

Masyhur Effendi, Perkembangan Dimensi Hak Asasi Manusia (HAM) \& Proses Dinamika Penyusunan Hukum Hak Asasi Manusia (HAKHAM), cet.I, (Bogor: Ghalia Indonesia, 2005), hal. 169

Andrey Sujatmoko, 2015, Hukum HAM dan Hukum Humaniter, Cetakan Pertama, RajaGrafindo Persada, Jakarta, hlm. 23-24

M. Budiari Itjehar, 2003, HAM Versus Kapitalisme, Insist Press, Yogyakarta, hlm. 128-129.

Wahyu Wagiman, et.al.(b), Naskah Akademis dan Rancangan Peraturan Pemerintah Prosedur Pemberian Kompensasi dan Restitusi: Usul Inisiatif Masyarakat (Jakarta: Indonesia Corruption Watch bekerjasama dengan Institute for Criminal Justice Reform dan Koalisi Perlindungan Saksi, 2007), hal.7

Zul Akrial, Kebijakan Legislatif tentang Restitusi dan Kompensasi kepada Korban, (Tesis), (Semarang: Program Studi Magister Hukum Universitas Diponegoro, 1998), hal. 77

Topo Santoso, Seksualitas dan Hukum Pidana, (Jakarta: IND.HILL-CO, 1997), hal. 64 